\title{
Counter-Cyclical Challenges of Fiscal Policy: A Comparitive Analysis of South Africa and Brics Countries
}

\author{
André Mellet \\ School of Economic Sciences, North-West University, Vanderbij/park, South Africa \\ Email: andre.mellet@nwu.ac.za
}

Doi:10.5901/mjss.2014.v5n21p251

\begin{abstract}
This study analyse the consequence of counter cyclical fiscal policy after the $2008 \mathrm{global}$ financial crisis. Fiscal stimulus programmes were proposed by the G20 member countries to reduce the negative impact on growth and employment of the global financial crisis. A mixed-method research methodology is followed to analyse the elevated government debt and budget deficits of developed countries and BRICS countries. The analysis of government debt in different countries pose a stark reality. Most countries do not have any scope to stimulate their economies anymore whilst the leaders of the G20 member countries propose exist strategies. This study highlights the importance of a new approach and new application of old fiscal theories to create sustained growth.
\end{abstract}

Keywords: Global financial crisis, counter cyclical policy, budget deficit, government debt, G20 countries, BRICS, South Africa, sustainable growth

\section{Introduction}

The global financial crisis, the negative effects of which could not be resolved through the application of fiscal and monetary policy, exchange rate policy and macro prudential policy alone, was experienced in 2008. Various interventions such as a stable exchange rate and overall financial stability (vital elements in the macro toolkit of policy makers) coupled with counter-cyclical fiscal policy are all needed to create economic stability and growth (Boutros-Ghali, 2010). The correct application of all these policies is sought that can contribute to the success of economic stability in any economy (Mitchell, 2005).

Each policy has its own challenges however. Debate prevails in the international markets regarding the degree of policy instruments applied and the mix of these instruments to create the maximum financial stability (Roubini, 2012; Soros, 2012). In this paper, the causes and challenges of high government debt created by counter cyclical fiscal policy is highlighted. This high government debt neutralizes the sustainability of a stimulatory stance of fiscal policy which is needed in the world.

Fiscal policy should aim to reduce debt in good times to the international norm of $2-3 \%$ of GDP (Mohr, 2004). The G20 countries and the IMF advised its members to apply counter-cyclical policy since the end of 2008 to reduce the negative impact of the global crisis. All the member countries increased their government spending as part of their macroeconomic tool kit to reduce the negative consequences of the global crisis (Duncan, 2012). The result of this increased spending is well known. The recovery in the world is very slow and increased growth rates worldwide are not sustained (Anon, 2012).

Soaring government debt is a new challenge that developed and caused other problems for policymakers to address (Dadush and Stancil, 2010). The debt levels of the United States of America and European countries, which are well above the international norm, are a prime example (Anon, 2011; Crook, 2012). Debt levels also soared in South Africa (Budget Review, 2012). However, there is another reason for concern. The main cause for the increase in South African government debt is an increase in current expenditure. This soaring debt, caused by incorrect spending policies, is investigated which neutralizes the desired effect of a sound counter-cyclical policy. This soaring debt increases the financial instability and reduces the creditworthiness of South Africa. The rethinking of economic theories and policy advice for South Africa in the wake of the global crisis is debated to reduce the negative consequences of soaring debt.

The analysis of increasing government debt and high budget debts in the selected developed countries relative to BRICS countries is based on a mixed-method of inquiry. The quantitative investigation of debt is based on a positivist paradigm. Empirical analyses comprised comparisons of government gross debt and fiscal balances between the 
developed G20 countries and BRICS countries. The qualitative investigation of debt is based on an interpretivist paradigm that involved the significance of debt on sustained growth. The quantitative research comprised comparisons of government debt in developed G20 countries and BRICS countries relative to real economic growth.

The background of the high government debt problem of G20 countries is firstly debated. Secondly, the proposals of the G20 countries are debated from a fiscal policy perspective to counter the negative consequences of the international recession which developed in 2009. Thirdly, the stance of government debt, for the period up to 2013, is analysed. Fourthly, comparisons amongst the developed countries and the BRICS countries indicate the severity of the international debt problem. Lastly, the specific debt scenario of South Africa is analysed. A new approach is debated with regard to counter cyclical fiscal policy and application of old theories to prevent future generations suffering from the fiscal mistakes of previous governments.

\section{Re-thinking Counter-Cyclical Policy}

The great depression of the 1930's created uncertainty within the international economic circles regarding the role of government during economic downturns. Industrialized countries faced an ongoing depression and the solution was unlikely to be found in classical economics (Vera, 2006). During this time John Maynard Keynes, the famous British economist, proposed a solution that changed the way how governments should act to reduce the negative impact on growth and aggregate demand. Investment, in the Keynesian system, is one of the determinants of aggregate demand and that aggregate demand is linked to aggregate supply via the multiplier (Keynes, 1973).

According to (Perez, 2003) Keynes suggested that government deficit spending should be used as a stabilization tool during recessionary cycles. According to (Mitchell, 2005) the theory of Keynes deficit spending of governments can provide stimulus to end a recession. The theory of Keynes stated that government spending must focus on large-scale public works programs (Vera, 2006). The theory of Keynes also stated that policy authorities must reduce government spending once the economic recession recovered in order to prevent inflation. The increase of investment, as contemplated in Keynesian economics, was influential for many decades since the 1930s.

The world experienced another financial crisis and recession since 2008. The Keynes theory of deficit spending by governments played an immense role in the recovery policies suggested by the $\mathrm{G} 20$ member countries. The $\mathrm{G} 20$ member countries agreed to implement deficit spending in combination with other measures to secure economic recovery in the world again. The result of these measures was soaring government debt especially in the developed countries. Since the 2008 financial crisis government debt also increased in South Africa. In a South African context, the implementation of countercyclical fiscal policies has to be analysed against the theory of Keynes as well as other theories that developed since the 1930s.

Since the theory of Keynes, another theory of fiscal policy developed in Europe in the 1950s and 1960s. The theory of fiscal policy states that policymakers have two objectives (Tanzi, 2004:4). The objectives are either the promotion of social welfare or the public interest of the inhabitants of a country. The social welfare depends on several indicators. Some of these indicators are of an economic nature and some are of a social nature. Examples of economic indicators are growth, inflation, income distribution and productivity. Examples of social nature are life expectancy, literacy rates, incidence of crime and incidence of illnesses. This normative theory explained how the fiscal authorities in the world should behave (Tanzi, 2004). This theory provided the theoretical framework for fiscal policy authorities to employ different instruments to promote desirable economic objectives. These instruments are various taxes, specific features of taxes, various categories of expenditure and specific features of expenditure.

Two other theories developed that challenged the principles of the theory of fiscal policy. The school of public choice theory was sceptic and elaborated on the suspicion that policymakers cannot separate their personal interest in the pursuit of public interest according to the mandate that they received from their constituencies (Tanzi, 2004). The positive theory of fiscal policy also developed in which the institutional set up of governments was analysed that determined the policy outcomes. This theory provided the institutional framework that is necessary for good policies to pursue objectives (Tanzi, 2004).

Literature on fiscal policy also reveals the effect of productive and unproductive spending by governments (Semmler et al., 2007). Public investment is defined as productive government expenditure and public consumption is defined as unproductive government expenditure. According to these empirical studies productive government spending financed by non-distortionary taxes achieves the best long term growth outcomes. On the other hand, if unproductive government spending is financed by distortionary taxes, a negative long term growth outcome can be expected.

According to Faraglia et al. (2011), fiscal policy and the debt structure of government must be jointly determined This approach differs from the traditional practice of debt management to only minimize the interest cost of government 
debt and to provide appropriate amounts of government bonds and therefore liquidity to the financial markets. This joint determination of policy and debt is crucial because it is influenced by the government's ability to react to unexpected fluctuations in either government expenditure or revenue. This joint determination of fiscal policy and debt structure of a government is important because it has an impact on the type of debt instruments that a government issue and the proportion of these debt instruments.

This overview of different fiscal policy theories is essential as it provides the foundation on which the group of twenty countries' fiscal policies are analysed and compared with Brazil, Russia, India, China and South Africa (BRICS) countries' fiscal policies .

\section{Role of Group of Twenty Countries (G20)}

Authorities in developed countries did not address all the risks in the financial markets and did not keep pace with financial innovations (Washington G20 Summit, 2008). Other factors, for example macroeconomic policies which were not coordinated in countries and structural reforms which were inadequate in various countries, contributed to the global crisis.

Authorities all over the world had to take swift action when the crisis erupted. Governments took over financial institution debt, assisted banks to recapitalize and introduced stimulatory policies to revive demand. According to (Ghosh, 2009) the IMF advised advanced countries to introduce large and lasting fiscal stimulus programs. The IMF indicated that these sustainable fiscal stimulus programs had to be coordinated across countries with a commitment to increase stimulus if the crisis deepened. The following press releases of the $\mathrm{G} 20$ countries confirm the coordinated fiscal policy strategies amongst member countries.

The G20 countries held several meetings after the outbreak of the global crisis in 2008. The following press release was issued after the first meeting in (Washington G20 Summit, 2008): "We have taken strong and significant actions to date to stimulate our economies, provide liquidity, strengthen the capital of financial institutions, protect savings and deposits, address regulatory deficiencies, unfreeze credit markets, and are working to ensure that international financial institutions can provide critical support for the global economy. ...... use fiscal measures to stimulate domestic demand to rapid effect, as appropriate, while maintaining a policy framework conducive to fiscal sustainability".

The following press release was issued after the third G20 meeting (Pittsburgh G20 Summit, 2009): "..........we reviewed the progress we have made since the London Summit in April. Our national commitments to restore growth resulted in the largest and most coordinated fiscal and monetary stimulus ever undertaken. The growth of the global economy and the success of our coordinated effort to respond to the recent crisis have increased the case for more sustained and systematic international cooperation. In the short-run we must continue to implement our stimulus programs to support economic activity until recovery clearly has taken hold".

The global financial crisis led to coordinated fiscal stimulus programs by the $\mathrm{G} 20$ countries and an increase in public debt of various economies. In addition to the stimulus programs of advanced economies, emerging economies also implemented fiscal stimulus policies which also led to increased public debt. Various emerging economies faced constraints on their fiscal space, namely to finance an increasing deficit without an increased borrowing cost. This constraint on the fiscal space of emerging economies limits their authorities to pursue fiscal expansion. The risk of such stimulation is that any adverse development in their financial markets forces their authorities to reconsider or reverse their sustained fiscal stimulation.

The G20 leaders expressed concern about sustained growth after the sixth G20 meeting (Cannes G20 Summit, 2011). According to the press release after the sixth $G 20$ meeting global growth has weakened and public debt levels increased. The projected growth in Europe was weaker and unemployment expected at the time to continue at higher levels than the international norm. The growth rate experienced in the US was lower than expected and emerging countries also experience slower growth. 
Figure 1: G20 countries fiscal stimulus and financial sector support

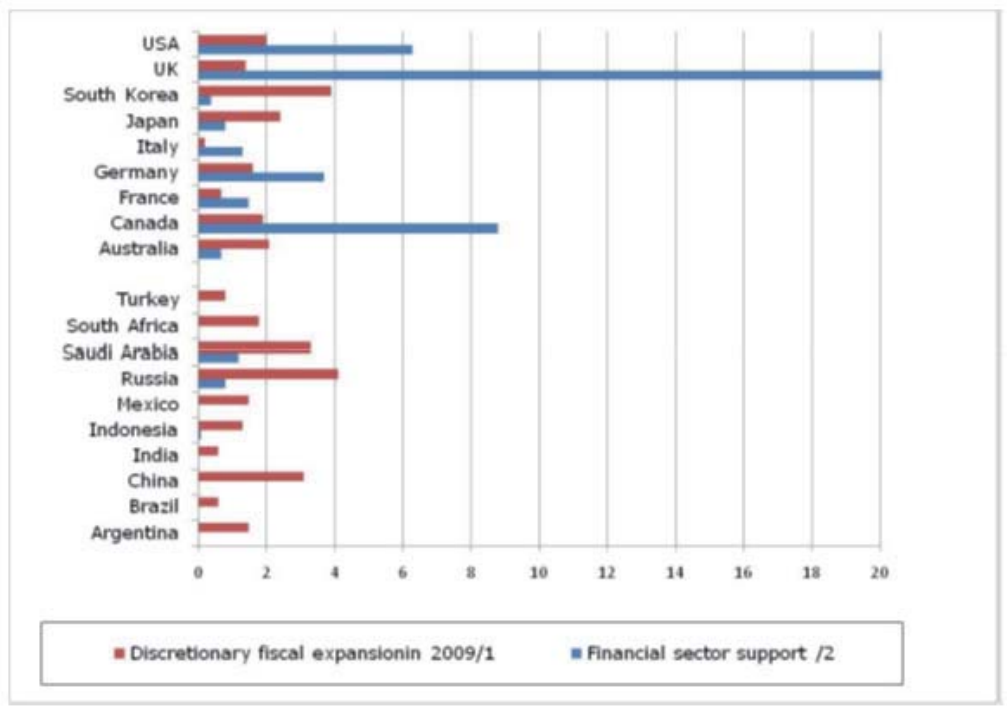

Source: World Bank (2009)

In Figure 1, the fiscal stimulation and financial sector support of the G20 countries is summarised. As far as monetary policy is concerned, monetary authorities recapitalized financial institutions and corporate sector institutions. These bailouts expanded the balance sheets of central banks apart from traditional easing of interest rates. As far as fiscal policy is concerned, fiscal authorities employed stimulatory packages and improved regulatory control measures. The average discretionary fiscal expansion for advanced economies amounted to 1.5\% of GDP in 2009 (World Bank, 2009). The average financial sector support amounted to 5.4\% of GDP in 2008. The average discretionary fiscal expansion for emerging economies amounted to 2.0\% of GDP in 2009 (World Bank, 2009). Financial sector support consisted of any capital injection by the authorities, purchase of assets and lending by treasury departments and any central bank support.

The G20 member countries implemented a mix of policy measures to secure recovery in the world. The short term policy measures included monetary policy stimulation or easing, the recapitalization of financial institutions, fiscal policy stimulation, bailout of corporate sector institutions by different authorities and the supply of liquidity by international financial organizations. In addition to these measures, the $\mathrm{G} 20$ member countries agreed to improve regulatory control of their financial systems. The longer term issues that developed after the application of these policy measures are global imbalances, accumulation of government debt in various countries and currency volatility as balance sheets were adjusted in various countries (Anon, 2010).

\section{Analysis of Government Debt}

The general government gross debt as percentage of GDP is reflected in Table 1. A selection of advanced countries (G7), European countries and BRIC countries data indicates, with the exception of India, that gross debt has increased since the global financial crisis erupted (IMF Fiscal Monitor, 2013). All the advanced countries debt ratios are in excess of the international norm of 40\% of GDP (Schuitema, 2013). Most of the BRIC countries satisfy the international norm of $60 \%$ of GDP, with the exception of Brazil and India. The data of the IMF is actual figures for $2008-2013$. 
Table 1: General government gross debt (\% of GDP)

\begin{tabular}{|l|c|c|c|c|c|c|}
\hline Countries & $\mathbf{2 0 0 8}$ & $\mathbf{2 0 0 9}$ & $\mathbf{2 0 1 0}$ & $\mathbf{2 0 1 1}$ & $\mathbf{2 0 1 2}$ & $\mathbf{2 0 1 3}$ \\
\hline United States & 75.5 & 89.1 & 98.2 & 102.5 & 106.5 & 107.1 \\
\hline France & 68.2 & 79.2 & 82.3 & 86.0 & 90.3 & 93.9 \\
\hline Germany & 66.8 & 74.5 & 82.5 & 80.5 & 82.0 & 78.1 \\
\hline Greece & 112.5 & 129.3 & 147.9 & 170.6 & 158.5 & 173.8 \\
\hline Italy & 106.1 & 116.4 & 119.3 & 120.8 & 127.0 & 132.5 \\
\hline Spain & 40.2 & 53.9 & 61.3 & 69.1 & 84.1 & 93.9 \\
\hline United Kingdom & 52.2 & 68.1 & 79.4 & 85.4 & 90.3 & 90.1 \\
\hline Canada & 71.3 & 81.4 & 83.0 & 83.4 & 85.6 & 89.1 \\
\hline Japan & 191.8 & 210.2 & 216.0 & 230.3 & 237.9 & 243.2 \\
\hline Brazil & 63.5 & 66.9 & 65.2 & 64.9 & 68.5 & 66.3 \\
\hline Russia & 7.9 & 11.0 & 11.0 & 11.7 & 10.9 & 13.4 \\
\hline India & 73.3 & 75.0 & 68.5 & 66.4 & 66.8 & 66.7 \\
\hline China & 17.0 & 17.7 & 33.5 & 25.5 & 22.8 & 22.4 \\
\hline South Africa & 27.8 & 31.3 & 35.8 & 39.6 & 42.3 & 45.2 \\
\hline
\end{tabular}

Source: IMF Fiscal Monitor (2013 \& 2014)

Table 2 reports the descriptive statistics of general gross government debts for the selected $\mathrm{G} 7$ countries relative to the BRICS countries for the period 2008 to 2013. From 2008 to 2013, the minimum level of general gross government debts was observed in Russia, whereas Japan had the maximum level of general gross government debts. Furthermore, the highest mean of general government gross debt (211.93\% of the GDP) is observed Japan; while Russia has the lowest mean (10.48\% of the GDP). The range and standard deviation shows that, for this 5 year period, countries such as Japan, the UK and the USA had a relatively high level of variation in general gross government debts within G20 countries; while Germany and Canada had a relative low variation in general gross government debts. Within BRICS countries, China and South Africa tend to have a high level of variation in general gross government debts.

Table 2: Descriptive statistics of general government gross debt

\begin{tabular}{|l|c|c|c|c|c|}
\hline & Range & Minimum & Maximum & Mean & Std. deviation \\
\hline USA & 32.60 & 75.50 & 108.10 & 96.65 & 12.40 \\
\hline France & 24.50 & 68.20 & 92.70 & 83.12 & 8.83 \\
\hline Germany & 15.70 & 66.80 & 82.50 & 77.78 & 6.09 \\
\hline Italy & 24.50 & 106.10 & 130.60 & 120.03 & 8.59 \\
\hline UK & 41.40 & 52.20 & 93.60 & 78.17 & 15.59 \\
\hline Canada & 15.70 & 71.30 & 87.00 & 81.95 & 5.58 \\
\hline Japan & 53.60 & 191.80 & 245.40 & 221.93 & 19.78 \\
\hline Brazil & 5.00 & 63.50 & 68.50 & 66.03 & 1.82 \\
\hline Russia & 3.80 & 7.90 & 11.70 & 10.48 & 1.33 \\
\hline India & 8.60 & 66.40 & 75.00 & 69.40 & 3.79 \\
\hline China & 16.50 & 17.00 & 33.50 & 22.97 & 6.06 \\
\hline South Africa & 14.90 & 27.80 & 42.70 & 36.58 & 6.08 \\
\hline
\end{tabular}

Source: Author's own calculations

Figure 2 reports the average percentage change in means of general gross government debt from 2009 to 2013 . The gross government debts appear to be growing at decreasing rate in $\mathrm{G} 20$ countries; while there is no consistent trend in the average growth of gross government debts in BRICS countries. The average growth rate tends to be high in G20 as compared to BRICS with exception of the year 2010. In 2011 and 2013, there was a decrease in average growth of general gross government debts within BRICS. Overall, both G20 and BRICS countries tend to follow a similar trend of declining growth in the gross government debts. This similar trend is confirmed by a significant positive correlation coefficient of 0.847 , which implies a positive association in the growth between the two economic blocks. However, this correlation is not statistically significant because the $p$-value $(0.33)$ is greater than $5 \%$. 
Figure 2: Average growth in gross government debts (G20 versus BRICS)

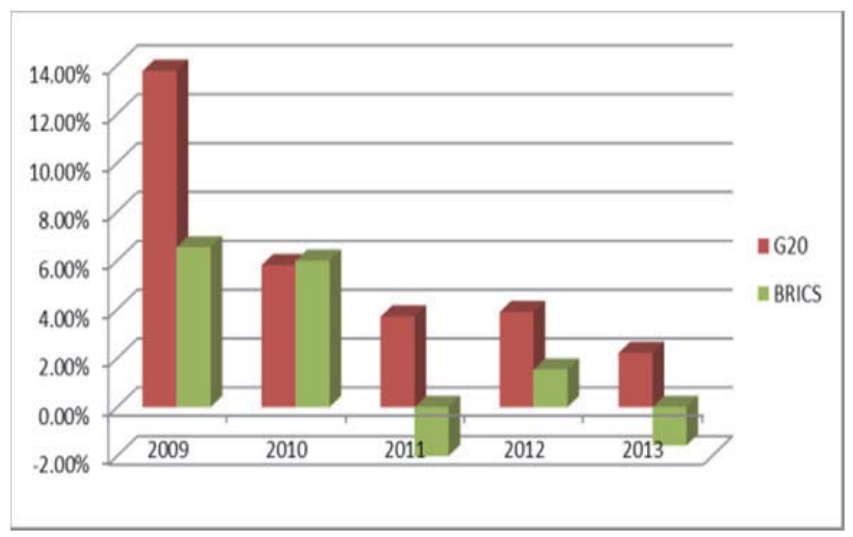

Source: Author's own calculations

The fiscal balances as a percentage of GDP is reflected in Table 3. A selection of advanced countries (G7), European countries and the BRIC countries data indicates, with the exception of Germany, that the negative fiscal balances increased since the global financial crisis erupted (IMF Fiscal Monitor, 2013). The fiscal balances on average paint a bleak picture for advanced countries relative to the emerging economies, with the exception of India. The data of the IMF is actual figures for 2008-2013.

Table 3: Fiscal balances (\% of GDP)

\begin{tabular}{|l|c|c|c|c|c|c|}
\hline Countries & $\mathbf{2 0 0 8}$ & $\mathbf{2 0 0 9}$ & $\mathbf{2 0 1 0}$ & $\mathbf{2 0 1 1}$ & $\mathbf{2 0 1 2}$ & $\mathbf{2 0 1 3}$ \\
\hline United States & -6.7 & -13.3 & -11.1 & -10.0 & -8.5 & -7.3 \\
\hline France & -3.3 & -7.6 & -7.1 & -5.2 & -4.6 & -4.2 \\
\hline Germany & -0.1 & -3.1 & -4.1 & -0.8 & -0.2 & 0.0 \\
\hline Greece & -9.9 & -15.6 & -10.7 & -9.4 & -6.4 & -2.6 \\
\hline Italy & -2.7 & -5.4 & -4.3 & -3.7 & -3.0 & -3.0 \\
\hline Spain & -4.5 & -11.2 & -9.7 & -9.4 & -10.3 & -7.2 \\
\hline UnitedKingdom & -5.1 & -11.4 & -10.1 & -7.9 & -8.3 & -5.8 \\
\hline Canada & -0.3 & -4.8 & -5.2 & -4.0 & -3.2 & -3.0 \\
\hline Japan & -4.1 & -10.4 & -9.3 & -9.9 & -10.2 & -8.4 \\
\hline Brazil & -1.4 & -3.1 & -2.7 & -2.5 & -2.8 & -3.3 \\
\hline Russia & 4.9 & -6.3 & -3.4 & 1.5 & 0.4 & -1.3 \\
\hline India & -8.6 & -10.1 & -8.7 & -8.4 & -8.3 & -7.3 \\
\hline China & -0.7 & -3.1 & -1.5 & -1.3 & -2.2 & -1.9 \\
\hline South Africa & -0.4 & -5.5 & -5.1 & -4.0 & -4.8 & -4.3 \\
\hline
\end{tabular}

Source: IMF Fiscal Monitor (2013 \& 2014)

Table 4 reports the descriptive statistics of the fiscal balance for the $\mathrm{G} 7$ countries relative to the BRICS countries for the period 2008 to 2013. For this period, the USA (-13.30) had the lowest value of fiscal balance in G20; while Germany reported a highest value $(-0.10)$ of the fiscal balances. In BRICS countries, India has the lowest value (-10.10) even lower than most of the G20 countries; while South African has the highest value (0.4) of fiscal balances. Furthermore, a high negative value of the fiscal balance is observed in the USA and India within G20 and BRICS, respectively. Range and standardization show that Russia (3.90) has the highest level of variation in the fiscal balances for the BRICS countries, while India(0.69) has the lowest variation of the BRICS countries. Fiscal balance for Russia and South Africa is the most unstable for the BRICS countries, while India is the most stable BRICS country. 
Table 4: Descriptive statistics of fiscal balances

\begin{tabular}{|l|c|c|c|c|c|}
\hline & Range & Minimum & Maximum & Mean & Std. deviation \\
\hline USA & 6.80 & -13.30 & -6.50 & -9.35 & 2.64 \\
\hline France & 4.30 & -7.60 & -3.30 & -5.25 & 1.76 \\
\hline Germany & 4.00 & -4.10 & -.10 & -1.43 & 1.72 \\
\hline Italy & 2.80 & -5.40 & -2.60 & -3.62 & 1.09 \\
\hline UK & 6.30 & -11.40 & -5.10 & -8.30 & 2.23 \\
\hline Canada & 4.90 & -5.20 & -.30 & -3.38 & 1.76 \\
\hline Japan & 6.30 & -10.40 & -4.10 & -8.95 & 2.41 \\
\hline Brazil & 1.90 & -3.10 & -1.20 & -2.28 & .79 \\
\hline Russia & 11.20 & -6.30 & 4.90 & -.53 & 3.90 \\
\hline India & 1.80 & -10.10 & -8.30 & -8.73 & .69 \\
\hline China & 2.40 & -3.10 & -.70 & -1.82 & .84 \\
\hline SA & 5.10 & -5.50 & -.40 & -4.10 & 1.88 \\
\hline
\end{tabular}

Source: Author's own calculations

Figure 3 reports the percentage changes in average percentage of fiscal balances from 2009 to 2013. In 2009, a large decrease in the average fiscal balances was observed in both G20 and BRICS countries. Overall, the both G20 and BRICS countries tend to follow a similar trend. This similar trend is confirmed by a positive correlation coefficient of 0.93 which is statistically significant ( $p$-value $=0.007$ ).

Figure 3: Percentage changes in the average fiscal balances (G20 versus BRCS)

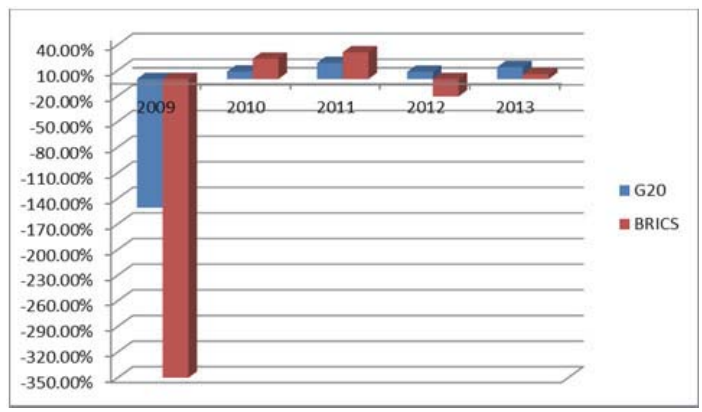

Source: Author's own calculations

The fiscal risks for many advanced countries remain elevated. The debt to GDP ratios in many advanced economies are at historic high levels because of coordinated international stimulation programs. Borrowing requirements remain high and several countries, for example the USA and the European Community, had to implement legislation to continue borrowing in the financial markets to supply necessary capital for their economies to operate efficiently. This sustained borrowing in the financial markets increases the risk of default as well as other risks such as the availability of future capital and borrowing at inflated market rates, which increase the cost to future generations.

Fiscal policy authorities in the G20 countries must consider the overarching outcomes of their decisions. The fiscal scope for many countries is limited whilst these authorities must continue to support a fragile international recovery. Furthermore, fiscal policy authorities have to consolidate their fiscal stance because it cannot be expected of future generations to pay the bill for polices applied after the 2008 financial crisis. The impossible policy becomes the norm that is, to continue to stimulate whilst creating a fiscal exit strategy. This consolidation of fiscal policies is reflected in the Cannes Summit G20 statement. The press release after the sixth G20 meeting stated that specific fiscal consolidation plans were essential to put government finances on a sustainable track (Cannes G20 Summit, 2011). It was recommended that member countries employ deficit reduction strategies to reduce debt-to-GDP ratios.

The G20 countries stated at the Cannes Summit that the various authorities in the member countries will support recovery, create financial stability and restore confidence through collective policy applications. Various group targets and 
individual country targets were agreed upon (Cannes G20 Summit, 2011). Examples include Australia, Canada, France, Germany, Italy, Korea, Spain and Britain who indicated they would reduce their government debt ratios by 2016 . Certain countries, for example Brazil, India, Indonesia, Mexico and South Africa must increase their infrastructure investment to increase growth and reduce unemployment. Member countries must provide formal and quality jobs through structural reforms of individual labour market policies. Member countries must enhance competition and reduce distortions in the market place. Other policies to be employed are for example structural reforms to boost productivity, tax reform, phasing out of distortive subsidies and the promotion of household savings. South Africa also has to enhance trade and investment in the southern region of Africa.

\section{Comparisons of Government Debt and Growth}

\subsection{USA and Europe Growth Statistics}

In Table 5 the annual growth rate of the United States of America is compared with a selection of advanced countries, European countries and BRICS countries. The fiscal risk for the USA poses a stark reality. The annual growth rate is subdued after the fiscal stimulation programs over several years. The fiscal balances as a percentage of GDP increased after 2008 which does not allow any space for the fiscal authority to continue with further stimulation programs. The IMF warned in July 2012 (IMF Survey, 2012) and again at the October 2012 Tokyo meeting that the world recovery depends on two conditions. Firstly, it is up to the United States to relieve the intended government spending cuts and tax increases that will take effect in 2013. Secondly, the Euro zone debt crisis must be resolved.

Table 5: IMF growth projections

\begin{tabular}{|l|c|c|c|c|}
\hline & Actual 2011 & Actual 2012 & Actual 2013 & Expected2014 \\
\hline United States & 1.8 & 2.8 & 1.9 & 2.8 \\
\hline France & 2.0 & 0.0 & 0.3 & 1.0 \\
\hline Germany & 3.4 & 0.9 & 0.5 & 1.7 \\
\hline Italy & 0.4 & -2.4 & -1.9 & 0.6 \\
\hline Spain & 0.1 & -1.6 & -1.2 & 0.9 \\
\hline UnitedKingdom & 1.1 & 0.2 & 1.8 & 2.9 \\
\hline Canada & 2.5 & 1.7 & 2.0 & 2.3 \\
\hline Japan & -0.6 & 2.0 & 1.5 & 1.4 \\
\hline Brazil & 2.7 & 0.9 & 2.3 & 1.8 \\
\hline Russia & 4.3 & 3.4 & 1.3 & 1.3 \\
\hline India & 6.3 & 3.2 & 4.4 & 5.4 \\
\hline China & 9.3 & 7.7 & 7.7 & 7.5 \\
\hline South Africa & 3.5 & 2.5 & 1.9 & 2.3 \\
\hline
\end{tabular}

Source: IMF World Economic Outlook (2013 \& 2014)

The IMF stated that the US economy could face a fiscal cliff (IMF Survey, 2012). A decline in GDP is very probable if the authorities do no act promptly to raise its federal debt ceiling. If this debt ceiling is not resolved, it could cause financial market disruption, loss in consumer and business confidence and significant negative spillovers to the rest of the world. An impossible fiscal policy is proposed for the United States, namely to continue to stimulate whilst creating a fiscal exit strategy. An eleventh hour deal was clinched on the sixteenth of October 2013 between the major political parties to end a partial government shutdown (Cowan and Ferraro, 2013). This legislation allowed the United States government to increase their debt ceiling of $\$ 16,7$ trillion and pulled the world's biggest economy back from the brink of a historic debt default that could have threatened financial calamity (Cowan and Becker, 2013). The prospects of sustained growth in the United States are not encouraging for several years to come.

In Table 5, the annual growth rate of a selection of European is also compared with the USA. The fiscal risk for the European countries poses a stark reality. The annual growth rate is negative or subdued after the fiscal stimulation programs over several years. The fiscal balances as a percentage of GDP increased after 2008 which does not allow any space for the fiscal authorities to continue with further stimulation programs.

All of the PIGS countries (Portugal, Ireland, Greece and Spain) received loans from various international institutions and are subject to conditions to reduce government debt (Dadush and Stancil, 2010). PIGS countries are 
subject to fiscal-exist strategies and fiscal structural reforms are required on condition of continuous financial assistance. High debt ratios are not sustainable and empirical studies done by the IMF proved that high government debt reduce growth (Cottarelli, 2010:11). The stark reality of these high debt ratios and fiscal-exist strategies means no prospect of sustained growth in the PIGS countries. Several other European countries also experience high government debt ratios and austerity fiscal measures are applied on condition of European and IMF bridging loans. The prospects of sustained growth in Europe are not encouraging for several years to come.

\subsection{BRICS Countries Growth Statistics}

In Table 1, the government debt of BRICS countries is displayed and in Table 5 the annual growth rate of the BRICS countries is displayed. The picture of these countries is vastly different than the growth versus debt scenario in the United States and the PIGS countries. The growth rates in most BRICS countries are elevated relative to the United States and Europe. The growth rates however declined due to a weaker external environment and a decline in domestic demand mainly in response to policy tightening measures in several BRICS countries.

Whilst the United States and the European countries experience increasing government debt, most BRICS countries experienced decreasing government debt with the exception of South Africa. An analysis of the peculiar debt scenario of South Africa follows in section 5.3. The government debt levels in many advanced economies increased because of coordinated international fiscal stimulation programs (Dadush \& Stancil, 2010). Regardless of fiscal stimulation programs, the government debt levels did not increase in the BRICS countries on a sustained basis mainly because of low government debt levels with the exception of South Africa. Most BRICS countries' fiscal policy authorities have fiscal scope to stimulate, but because of inflation risks and domestic growth of credit that can create asset bubbles, such stimulus programs are not implemented.

\subsection{South Africa's Peculiar Debt Problem}

Whilst the BRICS countries experience decreasing government debt, South Africa experience increasing government debt. The South African government decided soon after the outbreak of the 2008 financial crisis and in conjunction with G20 coordinated policy programs to apply counter cyclical fiscal policy. According to (Swanepoel and Schoeman, 2003), countercyclical fiscal policy requires government deficit and debt to swell during times of economic recessions and to decline during economic booms again. The government debt levels increased from a fairly low basis as percentage of GDP because of fiscal stimulation programs. But, there are various debt concerns to be highlighted.

Table 6: South Africa government debt (National and International)

\begin{tabular}{|c|c|c|}
\hline Year/R million & Total Gross loan debt & Percent increase y-0-y \\
\hline 2007 & 570846 & 10.0 \\
\hline 2008 & 627936 & 20.1 \\
\hline 2009 & 754266 & 26.3 \\
\hline 2010 & 952877 & 21.3 \\
\hline 2011 & 1155857 & 15.4 \\
\hline 2012 & 1334080 & \\
\hline 2013 (June) & 1428155 & \\
\hline
\end{tabular}

Source: South African Reserve Bank (2013)

The data displayed in Table 6 poses a stark reality. A countercyclical policy is implemented to increase macro demand when the South African economy grows below its long run potential. According to (Ireland, 1996) an effective countercyclical monetary policy aims to shield aggregate economic output from the effects of a shock in aggregate demand. Government debt however accelerates and continuous to rise at double digit percentages year on year since 2008. An analysis of government expenditure reveals that the rise was driven by consumption expenditure instead of capital expenditure. 
Table 7: Compensation of employees of consolidated government

\begin{tabular}{|c|c|c|c|}
\hline Year /R million & Compensation & $\%$ of Budget Expenditure & $\%$ of Non interest Expenditure \\
\hline $2008 / 09$ & 233345 & 32.9 & 35.7 \\
\hline $2009 / 10$ & 273980 & 33.3 & 35.7 \\
\hline $2010 / 11$ & 309802 & 35.3 & 38.1 \\
\hline $2011 / 12$ & 346714 & 36.3 & 39.5 \\
\hline $2012 / 13$ & 376561 & 35.6 & 38.9 \\
\hline $2013 / 14$ & 406182 & 35.3 & 38.6 \\
\hline
\end{tabular}

Source: Budget Review (2013)

Compensation of government employees is reflected in Table 7. One of the most alarming trends in government expenditure is the increased wage bill. Minister Gordhan stated (Budget Review, 2011): "Part of the revision to baseline allocations is the carry-through cost of the 2010 wage agreement, which requires an additional R39.4 billion for remuneration of employees over the MTEF period. The public service salary bill has doubled over the past five years. This cost constitutes just under 40 per cent of consolidated non-interest expenditure".

Minister Gordhan stated again (Budget Review, 2012) that government intends to cap public sector wage hikes at 5 per cent in 2012/13. This assertion has been met with doubt from many quarters. The common reason for this doubt is the threat of strike action, because industrial action has become the norm than the exception in South Africa. The increase in public sector wages for 2012 was in fact higher than the budgeted figure in February 2012. The continuous rise in wages above the inflation rate poses serious risks for fiscal policy application in South Africa. This high wage bill in conjunction with the rising interest bill, reduce the scope of capital expenditure by government.

Table 8: Social grants expenditure

\begin{tabular}{|c|c|c|c|}
\hline Year / R million & Budget - actual \& projected & Budget total Expenditure & \% of Budget Expenditure \\
\hline $2008 / 09$ & 70715 & 708489 & 10.0 \\
\hline $2009 / 10$ & 79260 & 823323 & 9.6 \\
\hline $2010 / 11$ & 87493 & 874172 & 10.0 \\
\hline $2011 / 12$ & 95962 & 972547 & 9.9 \\
\hline $2012 / 13$ & 104239 & 1055891 & 9.9 \\
\hline $2013 / 14$ & 113007 & 1149390 & 9.8 \\
\hline
\end{tabular}

Source: Budget Review (2013)

Social grants expenditure by government as percentage of total budget expenditure is reflected in Table 8 . The number of social grant recipients has grown in recent years. According to Minister Gordhan in the Budget Review (2012): "There will be a marked decrease in the spending on social grants as a percentage of GDP from 3,5\% in the 2011/12 period to 3,2\% over the MTEF. This decrease is the result of no planned grant increases occurring over the medium term and because economic growth is expected to outpace the growth in the number of grant recipients". The IMF reviewed the South African growth several times after the 2012 budget speech and reduced the growth rate for 2012 and 2013 (IMF World Economic Outlook, 2013). The forecasted decline in social grant spending as percentage of GDP will most probably not occur. Empirical research (Benos, 2009) proved that social expenditure does not improve growth.

Table 9: Public sector infrastructure expenditure

\begin{tabular}{|c|c|c|c|c|}
\hline Year/R million & Budget - actual \& projected & Actual Expenditure & \% spent of Budget & \% of Budget total expenditure \\
\hline $2008 / 09$ & 195809 & 193011 & 98.6 & 27.2 \\
\hline $2009 / 10$ & 245466 & 203637 & 83.0 & 24.7 \\
\hline $2010 / 11$ & 260407 & 177799 & 68.3 & 20.3 \\
\hline $2011 / 12$ & 226600 & 208286 & 91.9 & 21.8 \\
\hline $2012 / 13$ & 255905 & & & \\
\hline
\end{tabular}

Source: Budget Review (2012) 
The allocation of public resources with regard to infrastructure investment has not produced the growth results needed by an emerging nation such as South Africa. Actual capital expenditure as a percentage of capital expenditure in the budget and total budget expenditure is reflected in Table 9. According to the (Budget Review, 2012) for the period 2010/11, actual spending amounted to $68.3 \%$ of the amount actually been budgeted for. The actual capital expenditure declined as a percentage of total expenditure. According to the (Budget Review, 2012) for the period 2010/11, actual spending amounted to $20,3 \%$ of total expenditure. Capital expenditure suffered because the investment in announced infrastructure projects did not materialize because of capacity constraints.

According to Minister Gordhan in the (Budget Review, 2012): "The allocation of public resources to infrastructure investment has not always yielded the desired result. In 2010/11 actual spending was about 68 per cent of budget allocations. This figure masks wide disparities in delivery capacity. Some agencies and municipalities have a strong record of spending implementation, in others there are serious deficiencies in delivery capacity. This reflects the lack of sufficient skills in public sector".

If the actual budgeted capital expenditure occurred in the period 2008/09 to 2011/12, the government debt would be R145 billion higher. The annual budget deficit as percentage of GDP is therefore lower for the wrong reasons. Regardless of an improvement in the actual amount spent for the period 2011/12, there continue to be many areas within the broader public sector where infrastructure delivery is weak, characterized by delays, poor planning, lack of project management capacity and inadequate oversight (Budget Review, 2013).

\section{Conclusion}

The point of departure in the study was the fiscal policy challenges relating to the global financial crisis. The negative effects of the global crisis could not be resolved through the application of one policy. Debate prevailed amongst G-20 member countries and in the international markets about the degree of the different policy instruments applied and the mix of these instruments to create financial stability. Policy makers applied inter alia counter cyclical fiscal policy and government debt increased all over the world. The results indicate that gross government debt appear to grow in the selected developed countries whilst there is no consistent trend in BRICS countries. South Africa is the exception, where the gross government debt continuous to grow. High government debt neutralizes the sustainability of the stimulatory stance of fiscal policy.

The results indicate that fiscal balances decreased from the initial high levels in 2009 for developed and BRICS's countries. There are however a few exceptions in the developed countries for example United Kingdom and Japan. These exceptions are cases for further research. In the BRICS group of countries the fiscal balances of India and South Africa stay at high levels relative to 2009. The peculiar scenario of South Africa is analysed in this study. The scenario of India is another case for further research.

The results for South Africa indicate that government debt increased by double digits since 2008. An analysis of government expenditure reveals that the rise was driven by consumption expenditure instead of capital expenditure. Compensation of government employees are close to forty percent of non-interest expenditure and social grants expenditure is at ten percent of total expenditure. The results also revealed another expenditure concern, namely the capacity inefficiency of government to spend allocated capital according to the fiscus budget. Since the 2008 financial year, government capital expenditure was as low as $68 \%$ of budget and the allocated capital amount never materialised. These deficiencies in government actually reduced the published fiscal deficit for the wrong reasons.

Fiscal exit strategies are proposed by the G-20 member countries to eliminate the negative consequences of soaring government debt for future generations. Successful exit strategies emphasize cuts in government wages and transfers, over tax increases (Cottarelli, 2010). Subsidies to specific industries and increases in the compensation of the public sector wage bill should be disposed of (Ghosh, 2009). Passive unemployment benefits should be reduced and passive benefits (social grants) dilute incentives for the unemployed to seek employment (Cottarelli, 2012). Empirical research (Benos, 2009) proved that public expenditure on infrastructure exert a positive impact on growth.

A new approach is debated with regard to counter cyclical fiscal policy and application of old theories. Budget deficits and debt accumulation serve two purposes in developed countries. It provides the means to redistribute income and to minimize the deadweight loss of taxes as public goods and services are provided (Alesina \& Tabellini, 1987). Government expenditure needs a redesign. The composition of fiscal expenditure should be changed. Public infrastructure investment should increase and unproductive current expenditure should be reduced at all cost.

According to (Mitchell, 2005) capital and labour became more mobile in a competitive international economy. Budget deficits and how it is financed are important, but government spending that is to high create a burden on growth. All government programmes that yield low benefits and impose high costs must be scrapped. If fiscal policy is measured 
against the theory of fiscal policy, the school of public choice theory and the positive theory of fiscal policy, fiscal authorities should be concerned.

Government debt levels increased in developed and BRICS countries since the 2008 financial crisis. The main cause for the increase in South African government debt is soaring current expenditure whilst capital expenditure declined as a percentage of total expenditure. This soaring debt caused by incorrect spending policies, neutralizes the desired effect of a sound counter-cyclical policy. This soaring debt also increases the financial instability and reduces the creditworthiness of South Africa. South Africa is the only country of the BRICS country group that experiences rising government debt. South Africa has little margin for error to absorb any kind of macroeconomic shock without the debt ratio rising to even higher levels.

According to Evens (2010) an effective public service is a prior condition to infrastructural and industrial development. The rapid growth of East Asian countries can be attributed to a public bureaucracy that was recruited on meritocracy. Sustained growth depends on the ability of a public service to identify and execute investments efficiently. The South African government should therefore attract a high quality of employee to lay the foundation for long term growth. The composition of fiscal expenditure should be changed. Public infrastructure investment should increase and allocations of capital in the annual government budgets should be implemented. Unproductive current expenditure should be reduced at all cost

South Africa needs a redesign of government expenditure. The composition of fiscal expenditure should be changed and the mix between capital expenditure and current expenditure must change. In the absence of proper fiscal actions, investors will demand a much higher compensation for the risk of holding increasingly large amounts of public debt that the South African authority needs to issue to finance their unproductive means. The appearance of a dysfunctional governing system in society can be linked directly to the decisions and policies adopted by the ANC government after 1994 (Uys, 2011). The negative results of the transformation policies escalated after the 2008 global financial crisis. Countercyclical fiscal policy measures based on described theoretical principles should be implemented. Government should prioritise expenditure to avoid future fiscal cliffs.

\section{References}

Alesina, A., \& Tabellini, G. (1987). A Positive Theory of Fiscal Deficits and Government Debt in a Democracy. NBER Working Paper 2308, Cambridge, MA.

Anon. (2010). Bernanke sees an unusually uncertain future. Reuters.

Anon. (2011). IMF: World economy risks lost decade. Reuters.

Anon. (2012). Economic Overview: Recent developments in the global and South African economies. Department of Research and Information, Industrial Development Corporation, Johannesburg.

Benos, N. (2009). Fisal Policy and economic growth: Empirical evidence from EU countreis. Munich Personal RePEc Archive Paper 19174, Germany.

Boutros-Ghali, Y. (2010). Currency debate seen as symptom of deeper problem. IMF Survey, IMF, Washington, DC.

Cottarelli, C. (2010). Strategies for Fiscal Consolidation in the Post-Crisis world. IMF Fiscal Affairs Department, IMF, Washington, DC.

Cottarelli, C. (2012). Fiscal Policy and Employment in Advanced and Emerging Economies. IMF Fiscal Affairs Department, IMF, Washington, DC.

Cowan, R., \& Becker, A. (2013). US Senate still ironing out details of potential fiscal deal. Reuters.

Cowan, R., \& Ferraro, T. (2013). US Congress ends default threat, Obama signs debt bill. Reuters.

Crook, C. (2012). The one man who can save Europe. [Online] Available: http://www.bloomberg.com. (Feb 10, 2014)

Dadush, U., \& Stancil, B. (2010). Is a Sovereign Debt Crisis looming? [Online] Available:http://www.carnegieendowment.org/publications lindex.cfm. (Jan 20, 2014) Duncan, F. (2012). 2012: What are the risks? [Online] Available: http://www.moneyweb.co.za. (Dec $15,2013)$

Evens, P. (2010). Constructing a Democratic Developmental State in South Africa. Cape Town: HSRC Press.

Faraglia, E., Marcet, A., Scott, A. (2011). In Search of a Theory of Debt Management. Center for Economic Performance Discussion Paper 1083, The London School of Economics.

Ghosh, A. R., Chamon, M., Crowe, C., Kim, J. I., \& Ostry, J. D. (2009). Coping with the Crisis: Policy Options for Emerging Market Countries. IMF Staff Position Note 8, April 23 2009, IMF, Washington, DC.

Group of 20 Countries Press Release. G20 Summit on Financial Markets and the World Economy. (2008). Washington D.C., November 15 2008. [Online] Available: http://www.g20.org/en/financial-track/documents. (Dec 10, 2013)

Group of 20 Countries Press Release. G20 Summit on Financial Markets and the World Economy. (2009). Pittsburgh, September 25 2009. [Online] Available: http://www.g20.org/en/financial-track/documents. (Dec 10, 2013)

Group of 20 Countries Press Release. G20 Summit on Financial Markets and the World Economy. (2011). Cannes, November 42011. [Online] Available: http://www.g20.org/en/financial-track/ documents. (Dec 10, 2013)

IMF Fiscal Monitor. (2012). Balancing Fiscal Policy Risks, April 2012. IMF, Washington, DC. 
IMF Fiscal Monitor. (2013). IMF, Washington, DC.

IMF Fiscal Monitor. (2014). IMF, Washington, DC.

IMF Survey. (2012). Weak Global Recovery Depends on Progress in Europe and United States. [Online] Available:www.imf.org/external /pubs/ft/survey/ 2012.htm (Jan 10, 2014)

IMF World Economic Outlook. (2013). IMF, Washington, DC.

IMF World Economic Outlook. (2014). IMF, Washington, DC.

Ireland, P. N. (1996). The Role Of Countercyclical monetary policy. The Journal of Political Economy, 104 (4), 704-723.

Keynes, J. M. (1973). The General Theory of Employment Interest and Money. (13th ed.). Cambridge: Cambridge University Press.

Mitchell, D. J. (2005). The Impact of Government Spending on Economic Growth. Thomas A Roe Institute for Economic Policy Studies Paper 1831, 2005, Washington, DC.

Mohr, P., \& Fourie, L. (2004). Economics for South African Students. (3rd ed.). Pretoria: Van Schaik Publishers.

Perez, C. E. (2003). Chicago, Keynes and Fiscal Policy. Investigación Económica, 62 (246), 15-45.

Roubini, N. (2012). Markets on the move, but a brick wall looms. Reuters

Schuitema, J. (2013). The government debt trap. [Online] Available:http://www.moneyweb.co.za. (Feb 9, 2014).

Semmler, W., Greiner, A., Diallo, B., Rezai, A., \& Rajaram, A. (2007). Fiscal Policy, Public expenditure composition and Growth theory. World Bank Policy Research Working Paper 4405, World Bank, Washington, DC.

Soros, G. (2012). George Soros on the Euro Crisis. [Online] Available:http://www.moneyweb.co.za. (Feb 12, 2014).

South Africa. (2012). Budget Review. Pretoria: Government Printer.

South Africa. (2013). Budget Review. Pretoria: Government Printer.

South African Reserve Bank. (2013). Quarterly Bulletin, September, Research Department. Pretoria.

Swanepoel, J. A., \& Schoeman, N. J. (2003). Countercyclical Fiscal Policy in South Africa: Role and Impact of Automatic Fiscal Stabilisers. SAJEMS, 6 (4), 802-822.

Tanzi, V. (2004). Fiscal policy: When Theory Collides with Reality. Congress of the International Institute of Public Finance, 25 Augustus 2004, Milan.

TradingEconomics.com. (2013). [Online] Available:http://www.trading economics.com. (Feb 25, 2014).

Uys, S. (2011). Is South Africa in functional decay? [Online] Available:http://www.moneyweb.co.za. (Jan 20, 2014).

Vera, L. (2006). Fiscal policy, Universidad Central de Venezuela, Caracas

World Bank (2009) [Online] Available: http://www.worldbank.org/publications/documents\& reports.htm. (Jan 10, 2014). 
